\title{
Educational Project to Improve Problem-Based Learning in Architectural Construction Courses Using Active and Co-operative Techniques
}

Proyecto Docente para la Mejora del Aprendizaje de la Construcción Arquitectónica Basada en Problemas con Técnicas Activas y Cooperativas

Oriol Pons-Valladares (Main Author) (Contact Autor)

Department of Building Technologies I, Universidad Politécnica de Cataluña Barcelona Tech.

Av. Diagonal 649, 08028 Barcelona, Spain.

0034649781652,0034936892725

oriol.pons@upc.edu

José M. González-Barroso

Department of Building Technologies I, Universidad Politécnica de Cataluña Barcelona Tech.

Jose.M.Gonzalez@upc.edu

\begin{abstract}
This article presents a Project for Teaching Innovation (PTI) for the improvement of teaching practices in the Construction 1 course at the Architecture School of Barcelona (ETSAB). Since the 1980s this course has successfully made use of Problem-Basic Learning (PBL); however over the last ten years, various learning problems have arisen and become endemic. This PTI has been designed and implemented with the intention of solving this situation, and has been evaluated to determine the viability of its application. This design has been developed by the teaching team and assessed by experts from the University, which has consisted of drawing up strategies for improving each one of the identified problems. These strategies consist of incorporating new activities, and active and co-operative learning techniques. For the purposes of evaluation, indicators were designed to control the functioning of each strategy, to collect and analyse data for each indicator, and to draw conclusions. To summarise, this project has provided a means to start resolving the problems faced by the Construction $1 \mathrm{PBL}$ and, at the same time, has created knowledge about the success of the techniques, activities and indicators used in this PTI which may be of use to future teaching projects.
\end{abstract}

Keywords: Learning, Co-operative Learning, Innovation, Architecture, Construction.

\section{Introducion}

In project based learning (PBL), students develop projects - (in other words complex problems or challenges) which they have been set, which involve a process of design, investigation and decision making, allowing the students to work independently over a long time period, at the end of which they present a realistic project (Thomas, 2000).

Precisely PBL had already been used successfully at the Architecture School of Barcelona (ETSAB) in the Barcelona Tech University (UPC) in most subjects since the 1980s. But over the last decade various problems have been detected in these PBL, which until now have proved impossible to resolve. The Project of Teaching Innovation (PTI) presented in this article aims to solve these weaknesses by means of progressively applying active and co-operative learning activities. These activities were already known to the scientific community but this PTI presents the following innovations: a) they have been applied in order to improve a PBL, and b) they have been specifically adapted to the specific case of teaching Architectural Construction. This article first presents the case study, followed by the method and the discussion of the results, from which the final conclusions are based.

\section{State of the art}

\section{Rafael López-Olivares}

Department of Building Technologies I, Universidad Politécnica de Cataluña Barcelona Tech.

rafael.lopez-olivares@upc.edu

\section{Iván Arias}

Department of Building Technologies I, Universidad Politécnica de Cataluña Barcelona Tech.

iarias81@hotmail.com

Manuscript Code: 434

Date of Reception/Acceptance: 08.09.2014/01.06.2015

\section{Resumen}

Este artículo presenta un Proyecto de Innovación Docente (PID) para la mejora de las prácticas de la asignatura Construcción 1 de la Escuela de Arquitectura de Barcelona (ETSAB). Esta asignatura ya incorporaba exitosamente Problem-Basic Learning (PBL) en los años 1980 pero desde los últimos 10 años se han detectado problemas de aprendizaje y se han convertido en endémicos. Con el objetivo de mejorar esta problemática se diseñó e implantó este PID, el cual también se evaluó para determinar la viabilidad de su aplicación. El diseño se realizó por parte del equipo docente con el asesoramiento de expertos de la Universidad. Consistió en construir estrategias de mejora de cada uno de los problemas. Las estrategias consistían en incorporar nuevas actividades y técnicas de aprendizaje activo y cooperativo. Para su evaluación se diseñaron indicadores para: controlar el funcionamiento de cada estrategia, recoger datos de los indicadores, analizarlas y llegar a conclusiones. En resumen, este proyecto ha permitido empezar a resolver los problemas que tenía el PBL de Construcción 1 y, al mismo tiempo, se han adquirido conocimientos sobre la idoneidad de las técnicas, actividades e indicadores de este PID que pueden ser útiles para futuros proyectos docentes.

Palabras Claves: Aprendizaje, Aprendizaje Cooperativo, Innovación, Arquitectura, Construcción.

learning (Takahashi \& Saito, 2013), in which the students learn entirely through their understanding of a problem and resolving it with the objective of acquiring knowledge relating to the problem being studied, and developing skills to resolve similar, as well as more general problems (Barrows, 1980).

The incorporation of projects, coursework and problems has a long tradition in teaching across all educational levels. However the first PBL were first successfully introduced towards the end of the 20th century, as for example "Expeditionary Learning" (EL) by Outward Bound (Cambpbell et al., 1998) in primary schools, and "problem-based learning" (Barrows, 1992) in medical training at University level. During the same period other active learning methods were defined and introduced which involved the students more, placing greater emphasis on their skills and developing their abilities and values in higher level forms of learning (analysis, synthesis and evaluation) (Bonwell et al., 1991). Since then, these methods have been evaluated in university teaching and have been demonstrated to produce better results than their predecessors referred to as traditional teaching, in which students took a more passive role based on listening, and attending lectures (Prince et al., 2004). At the end of the 20th century co-operative learning methods were introduced such as 'the puzzle', first in primary schools (Aronson, 2012) and later in universities (Traver et al., 2006, Tempelear et al., 2013). 


\section{Description of the problem}

This article focuses on "Construction 1" that is an ETSAB core subject for second year Architecture students (Pla, 2010). This study concerns the practical sessions, which are conducted once a week during three hours with a reduced number of students and in work groups. Teaching is based on problem-solving of three exercises: 1) masonry, 2) structure and 3) external building envelope (Gonzalez et al., 2014). The specific competencies of this course are based on the student's deepening knowledge of the discipline of construction and in its practical application, at the same time as establishing relationships between technical knowledge and the design project in order to give it constructional sense. The objectives of the course are that the student: a) learns and understands the typological structure of the principal elements of the construction; b) learns the basic material and technical characteristics of the principal types of construction elements; c) critically evaluates the characteristics of each of these aspects in order to orientate and justify decision making in the design project; d) becomes more capable of developing design solutions for specific parts typically found in housing construction.

A total of 339 students participated in this project. The work groups for exercises were of between 18 and 27 students per professor and classroom from 2008 to 2013, and 40 students from 2013 on. The students admitted to the course must have previously passed the first year architecture degree course "Bases per a la Tècnica" (Basis for technology) (Pla, 2010) with a minimum grade of $50 \%$.

As already mentioned in the introduction, during the last decade the PBLs for the course in question were found to have a number of problems. From 2008 to 2011, a study was conducted to analyse these problems which involved the course teachers taking into account the classes, exams and student coursework, the grades and university questionnaires such as Student Evaluation of Educational Quality (SEEQ). This study considered information from 113 students from which the following six issues were detected: P1) the evaluation of the practical exercises and exams demonstrated that the students had not acquired basic competency; P2) most students only attended the supervision of their own projects; P3) most students were reticent about taking an active role or participating in group activities, in contrast to various studies relating to other PBL cases (Hussain et al., 2007); P4) there were anomalies in participation as some groups and up to $20 \%$ of students did not hand in the practical exercises or complete the course; P5) the majority of students were dissatisfied with the course and P6) the seven generic competencies stipulated by the UPC were not attained: entrepreneurship and innovation, sustainability and social commitment, a third language, efficient oral and written communication, teamwork, effective use of information resources and self-directed learning (ICE, 2008), even though the bibliography includes PBL learning case studies which show that such methods encourage the learning of similar competencies (Kumar \& Natarajan, 2007, Kohl et al., 2008).

\section{Methodology}

With the objective of resolving the aforementioned six existing problems, the PTI which was defined and applied consisted of: 1) defining strategies to improve each problem; 2) defining indicators to evaluate the strategies applied; 3) to collect, process and evaluate the results obtained in each indicator, and consequently to evaluate the strategies and the PTI.

\section{Strategies for improvement}

The following strategies for improvement were drawn up to answer the six problems mentioned in section 3 :

S1 - To improve the process of learning through: a) co-operative learning techniques, b) active learning techniques, c) manual activities such as building models d) out of class activities such as visits to buildings as well as improving the process of evaluation and its results using e) examples and rules for the exercises, f) brainstorming techniques with the students to define a part of the exam.

S2 - To encourage attendance by means of co-operative learning techniques, requiring the participation of all the students throughout the entire session.

S3-To increase the level of involvement using active techniques requiring the students to take on an active rather than passive role, while at the same time making these techniques a more significant part of the evaluation.

S4 - To improve participation and reduce student absence through using activities which increase interest and motivate the students to learn demonstrating the use and application of Architectural Construction, both to other courses and to the professional life of the architect.

S5 - To satisfy the needs to the students by reorganising the techniques, activities and parts of the subjects criticised, after having checked that the student complaints correspond to the real situation.

\begin{tabular}{|c|c|c|c|c|c|c|c|c|c|c|c|}
\hline \multirow{2}{*}{ Problems } & \multirow{2}{*}{ Strategies } & \multicolumn{10}{|c|}{ Techniques and activities } \\
\hline & & T1 & $\mathrm{T} 2$ & T3 & T4 & T5 & T6 & $\mathrm{T7}$ & $\mathrm{A} 1$ & $\mathrm{~A} 2$ & A3 \\
\hline P1- Poor learning process & $\begin{array}{l}\text { S1- Improvement with new techniques } \\
\text { and activities }\end{array}$ & $x$ & $\mathrm{X}$ & $\mathrm{x}$ & $X$ & $x$ & $x$ & $\mathrm{X}$ & $\mathrm{x}$ & $\mathrm{X}$ & \\
\hline P2- Low attendance & $\begin{array}{l}\text { S2- encourage attendance using new } \\
\text { techniques }\end{array}$ & $\mathrm{x}$ & $\mathrm{X}$ & $\mathrm{x}$ & & $x$ & $\mathrm{x}$ & & & & \\
\hline P3- low involvement & $\begin{array}{l}\text { S3- Increase involvement with new } \\
\text { techniques }\end{array}$ & $\mathrm{X}$ & $\mathrm{X}$ & $\mathrm{x}$ & & $x$ & $x$ & & & & \\
\hline $\begin{array}{l}\text { P4- Improvable } \\
\text { participation }\end{array}$ & $\begin{array}{l}\text { S4- Improve participation using new } \\
\text { activities }\end{array}$ & & & & & & & & $\mathrm{x}$ & $x$ & $\mathrm{x}$ \\
\hline P5- Student dissatisfaction & $\begin{array}{l}\text { S5- Improve techniques through gradual } \\
\text { modification }\end{array}$ & & & & $\mathrm{X}$ & & & $\mathrm{X}$ & & & \\
\hline P6- Unfilled competencies & S6- Incorporate new activities & & & & & & & $x$ & & & $x$ \\
\hline
\end{tabular}

Key: T1- Puzzle; T2- Think, Pair and Share (TPS); T3- Brainstorming; T4- Examples and rubric; T5- Debate; T6- Oral presentations with student comments; T7- Digital portfolio; A1- Models; A2- Visits to buildings; A3- Lectures in other languages. 
S6 - To incorporate new activities in order to attend to the generic competencies established by the University, bearing in mind that these are done in other subjects.

These strategies were formalised in a set of techniques and activities which were first incorporated into this course. To do so, meetings were held between the teachers and members of the Institute of Education Science (ICE) from the University. The techniques introduced were the following: T1- Puzzle; T2Think, Pair and Share (TPS); T3- Brainstorming; T4-Examples and rules; T5- Debate; T6- Oral presentation with comments from the students; T7- Digital portfolio. The following activities were incorporated: A1- Models; A2- Visits to buildings; A3- Lectures in other languages. Table 1 relates the six problems detected in the course, to the six strategies and these techniques. The majority of these techniques and activities were known of and have already been applied in other universities, but had to be adapted to the teaching of architectural construction and the reality of the subject.

T1 - The puzzle is a co-operative learning method which allows for dynamic and beneficial work for the students. It requires the students to be divided into base groups, normally three people. Each individual of the group is assigned the role of a different expert, thereby forming three groups of experts across the whole class. The puzzle takes the following form: 1) each expert prepares their own article of text individually; 2) the groups of experts meet to discuss their text together in order to deepen an understanding of their own text; 3 ) the base groups meet, and each expert explains and shares his or her knowledge previously discussed with the objective that all the students gain a better understanding of each text. The majority of these experiences is based on texts or articles, but those in this PTI are significantly different (Pons et al., 2012) as shown in Table 2. Puzzles about different construction parts of the building and their representation have been made: a) floor plants; b) structures sections; c) facades and d) facade details. In this last case, each class group had approximately 21 students divided into 7 groups, each one of whom studied a different building; the seven buildings were the same in the three classes. The puzzle was made up of 63 students, with three main class-groups and 7 groups of experts of 3 types and 3 with students in each group.

T2- "Think, pair and share (TPS)" is a co-operative work method carried out in pairs, in which the students first reflect individually upon a topic and then share their thoughts with their partner. This method has been in use since the 1980s (Lyman, 1981) and continues to be used in Universities today (Fitzgerald, 2013). In this educational project the TPS was the prelude to a debate, and served to prepare each group. The students, first individually, analysed four different facades studying their thermal, water resistant, acoustic, illumination and mechanical behaviour. After this, students were grouped into pairs and shared their analysis with their partner.

\begin{tabular}{|c|c|c|c|c|c|c|c|c|c|c|}
\hline Part & Object & Character & Classes & Students & Base & Experts & Time & Classrooms & Area & Other \\
\hline a. Floors & Drawings & Analysis & 1 & 21 & 7 & 3 & 3 & \multirow{3}{*}{1} & \multirow{4}{*}{91,4} & \multirow{4}{*}{$\begin{array}{c}\text { Example and } \\
\text { rubric (Allen, } \\
2004)\end{array}$} \\
\hline b. Structures & Outlines & Proposals & 1 & 21 & 7 & 3 & 3 & & & \\
\hline c. Facades & Details & Analysis & 1 & 21 & 7 & 3 & 3 & & & \\
\hline $\begin{array}{l}\text { d. Facade } \\
\text { details }\end{array}$ & Details & Proposals & 3 & 21 & 3 & 7 & 3 & 3 & & \\
\hline
\end{tabular}

Key:

Part: construction part. Object: The object of study worked on in the puzzle. Character: Whether the puzzle was analytical (analysing the object) or propositional (presenting proposals for the object). Classes: number of work groups participating in the puzzle. Students: Approximate number of students in the work groups. Base: The number of students in the base group. Experts: Number of students in the groups of experts. Time: Duration of the puzzle in hours. Classrooms: number of classrooms. Area: Area of the classroom used in $\mathrm{m} 2$. Auxiliary material: Extra material used in the puzzle.

T3- Brainstorming (Faickney, 1963) is a structured cascade of ideas, which generates as many ideas as possible and gives the opportunity for everyone's voice to be heard. During the activity, questions are neither evaluated nor discussed so that the brainstorming may be as fluid as possible. One of the problems that this method raises is that it can only be done with small groups. In this educational project, brainstorming was used in three cases: a) for finding arguments in defence of the best facade for the debate activity, b) for deciding on questions to ask an expert following a lecture, c) for proposing questions for the exam.

T4- Examples and rules (Brown, 2008) are a format for the presentation and evaluation of exercises with maximum transparency and tractability. The teaching team presents the activities with an outline example which describes in exhaustive detail what the students have to do and hand in, along with rules governing how each part will be evaluated. In the course in question, these documents were posted on Moodle so that all students would have access to the information.

T5- The debate is a widely used activity which is both well known and strongly defended (Parcher, 1998). In this project the debate focused on which was the best type of facade for the ETSAB classrooms. This was done with a work group of approximately 21 students which was divided into three facade groups of seven students each. Each group was assigned one type of facade which may provide the solution, the students then studied it using puzzles, TPS and brainstorming in order to prepare arguments in favour of it being the best facade. Following this, each facade group presented their arguments in favour to the whole class, trying to overturn the arguments in favour of the other facade groups and finally the entire class decided which was the best facade for ETSAB.

T6- Oral presentation (King, 2002) of this project was a pre-prepared and structured presentation of the PBL. This presentation was prepared in groups of three students and included an introduction, discussion and conclusions, and this was then made to the entire class. In this study, the students from other groups discussed and presented their commentaries together with the course exercise.

T7- The digital portfolio (Wesel \& Prop, 2008) is a web page in which students show interesting parts from their learning process. The digital portfolio offers many advantages compared to a paper portfolio as it can incorporate hyperlinks, attaching multimedia resources which is easily shared. In this case, the students, either individually or in groups, worked on the specific learning process from Construction 1 , even if this was linked to prior knowledge and may have formed part of an interdisciplinary portfolio. The objective is to show and present the most outstanding parts of the course that they have learnt, from the contents of the teaching material and 
student exercises to the expectations, evidence of learning, sources of information, reflection on and critical analysis of the learning process, comments and reflections, evaluations of the course etc. This was done individually in phase 3 and in groups of two or three students in phases 4 and 5 . The exercises and the indicators filled in by the students may be seen in the digital portfolios and are presented in the following section (Ruiz, 2012).

A1- Models (Aebli, 2002) have the advantage that they may be observed from all angles as three-dimensional representations of reality at a reduced scale. This is neither possible with drawing or plan. Many models can be dismounted so as to show the construction process of the element in question. Through using models the student tackles the problems of visibility, and spatial conception. In our case the model was a physical construction made with modelling materials of one part of a structure at a predetermined scale, either realistic or conceptual. This was carried out in groups of three students and developed with the help of puzzles.

A2- Visits to buildings consisted of the whole class visiting the buildings which each group of three students had studied. During the visit to each building, the students who had studied it explained it and the entire group made comments.

\begin{tabular}{|c|c|c|c|c|c|c|c|c|c|c|c|c|c|c|}
\hline \multirow{2}{*}{ Phase } & \multirow{2}{*}{$\begin{array}{l}\text { Academic } \\
\text { year }\end{array}$} & \multirow{2}{*}{ N1 } & \multirow{2}{*}{ N2 } & \multirow{2}{*}{ Exercise } & \multicolumn{10}{|c|}{ Techniques and activities } \\
\hline & & & & & T1 & T2 & T3 & T4 & T5 & T6 & $\mathrm{T7}$ & A1 & A2 & A3 \\
\hline \multirow{4}{*}{ f1 } & \multirow{4}{*}{$\begin{array}{c}2010-2011 \\
\text { part } 2\end{array}$} & \multirow{3}{*}{17} & \multirow{3}{*}{1} & 1) Construction & & & & & & & & & & \\
\hline & & & & 2) Structure & $x$ & & & $x$ & & & & & & \\
\hline & & & & 3) Facade and roof & $x$ & & & $x$ & & & & & & \\
\hline & & 27 & 1 & All & & & & & & & & & & \\
\hline \multirow{4}{*}{ f2 } & \multirow{4}{*}{$\begin{array}{l}2011-2012 \\
\quad \text { part } 1\end{array}$} & \multirow{3}{*}{21} & \multirow{3}{*}{1} & 1) Construction & & & & & & & & & & \\
\hline & & & & 2) Structure & & & & & & & & & & \\
\hline & & & & 3) Facade and roof & & $x$ & $x$ & $x$ & $x$ & & & & & \\
\hline & & 22 & 1 & All & & & & & & & & & & \\
\hline \multirow{3}{*}{ f3 } & \multirow{3}{*}{$\begin{array}{l}2011-2012 \\
\text { part } 2\end{array}$} & \multirow{3}{*}{$21 \times 3$} & \multirow{3}{*}{3} & 1) Construction & & & & $x$ & & & $x$ & & & \\
\hline & & & & 2) Structure & $x$ & & & $x$ & & & $x$ & & & \\
\hline & & & & 3) Facade and roof & $x$ & $x$ & $x$ & $x$ & $x$ & $x$ & $x$ & & $x$ & $x$ \\
\hline \multirow{3}{*}{ f4 } & \multirow{3}{*}{$\begin{array}{c}2012-2013 \\
\text { part } 1\end{array}$} & \multirow{3}{*}{$24 \times 3$} & \multirow{3}{*}{3} & 1) Construction & & & & $x$ & & & $x$ & & & \\
\hline & & & & 2) Structure & $x$ & & & $x$ & & & $x$ & & & \\
\hline & & & & 3) Facade and roof & $x$ & $x$ & $x$ & $x$ & $x$ & $x$ & $x$ & & $x$ & $x$ \\
\hline \multirow{3}{*}{ f5 } & \multirow{3}{*}{$\begin{array}{c}2012-2013 \\
\text { part } 2\end{array}$} & \multirow{3}{*}{$18 \times 2$} & \multirow{3}{*}{2} & 1) Construction & & & & $x$ & & $x$ & $x$ & & & \\
\hline & & & & 2) Structure & $x$ & & & $x$ & & $x$ & $x$ & & & \\
\hline & & & & 3) Facade and roof & $x$ & $x$ & & $x$ & $x$ & $x$ & $x$ & & & \\
\hline \multirow{3}{*}{ f6 } & \multirow{3}{*}{$\begin{array}{c}2013-2014 \\
\quad \text { part } 1\end{array}$} & \multirow{3}{*}{$39+42$} & \multirow{3}{*}{2} & 1) Construction & & & & $x$ & & $x$ & & & & \\
\hline & & & & 2) Structure & $x$ & & & $x$ & & $x$ & & $x$ & & \\
\hline & & & & 3) Facade and roof & & $x$ & & $x$ & $x$ & $x$ & & & & \\
\hline
\end{tabular}

Key: N1- Number of students; N2- Number of groups; T1- Puzzle; T2- Think, Pair and Share (TPS); T3- Brainstorming; T4- Examples and rubric; T5- Debate; T6- Oral Presentation with student comments; T7- Digital portfolio; A1- Models; A2- Building visits; A3- Lectures in other languages.

A3- The lectures in other languages consisted in lectures by experts from another country given in a topic relating to the course subject. In this course following the lecture, the coursework group thought up questions using brainstorming and then asked the expert.

This PTI was started in 2011 and finished in 2014. During this period, the strategies for improvement have been followed and the techniques and activities previously mentioned have been incorporated. This has been implemented in a gradual and progressive way according to the advice of the ICE, based on earlier experiences and writings (Biggs, 2011). This PTI strategy remained flexible at all times and was adapted to learning needs, maintaining dialogue between teacher and students throughout the whole process. This was done in six phases over six terms between 2010-11 and 2013-2014. In phases 1 and 2 , at the same time that the project was introduced with a work group, another control group was maintained which in contrast did not do a project. The project was then applied to all three work groups (for the afternoon group) from phase three onwards. From phase 5 on, the course was modified to have only two work groups because the University increased the number of students by reducing the number of teachers for economic reasons (Pinto, 2011). Table 3 summarises these phases in relation to the academic years, students, groups, exercises, techniques and activities.

\section{Indicators to evaluate the improvement strategies.}

The following eleven indicators were used to evaluate the improvement strategies:

11) Questionnaire SEEQ: a Student Evaluation of Educational Quality (Richardson, 2005). This was collected twice per term during phases 1 to 4 ;

12) Course satisfaction: a questionnaire regarding satisfaction, in which the student is asked to write openly and without prior limitations which sessions have been most useful, least useful...

13) University questionnaire: A SEEQ-type questionnaire promoted by the university and directed to students referring to teaching performance and subjects. This was collected every 
second term except during 2011-2012 when it was collected during both terms.

14) Academic evaluation: The result of evaluating the coursework made by students during the practical classes. This also shows the students who completed the hand-in and those who abandoned the course.

15) Peer-to-peer evaluation (Sanchez et al., 2011) is the student evaluation of the work of their fellow students. This was used in the third phase where each student marked the portfolio of another student using the university intranet platform.

16) Coursework Comparative Evaluation: A study of the exercises handed in by students from the previous courses and in the different stages of the PTI in order to determine if these showed that the students had learnt what was hoped for.

17) Pre-test, post-test: A pre-test and post-test to assess the level of knowledge before and after the exercise (Dimitrov et al., 2003). This was carried out in phases 3 and 4 of the practical exercise number three on facades for three groups, and roofs and during phase 6 for the exercise two on structures for two groups. This indicator has been assessed when significant changes were made such as: a) the implementation of various new active methods in sessions 3 and 4 ; b) the incorporation of a new and completely different active method such as the model in session 6 .

18) Learning reports: These took the form of a list of questions before and after doing the coursework, and were completed in phases 2 and 3 . The questions are compiled in the annex. These were accompanied by examples and rules.

19) Dedication record: These registers recorded the time dedicated to the exercises on the part of both the students and teachers.

110) The register of work completed in the classroom and handed in, with the objective of keeping a record of attendance.

I11) Distribution of work: Students evaluated the percentage of work carried out by each student in the three exercises.

112) Filming: An audiovisual recording was made of the third phase by ETSAB.

113) Teacher evaluation: The evaluation of the course made by the teaching team based on both objective indicators such as the twelve already mentioned, as well as day to day feedback.

Table 4 presents the indicators which were collected to evaluate each one of the improvement strategies. These indicators and when to apply them, was decided at meetings with experts in university education and the teaching team. Many different indicators have been collected with the intention of finding the most useful to the professors, and which would also have the widest acceptance by the students. At the same time, they have been alternated to avoid overloading the students with data collection, as already compiled in the literature (Pérez-Martínez et al., 2010).

Table 4. Indicators collected for the analysis of the case study. Self-elaborated by the authors.

\begin{tabular}{|c|c|c|c|c|c|c|c|c|c|c|c|c|c|}
\hline \multirow{2}{*}{ Strategies } & \multicolumn{13}{|c|}{ Indicators } \\
\hline & 11 & 12 & 13 & 14 & 15 & 16 & 17 & 18 & 19 & 110 & 111 & 112 & 113 \\
\hline S1- Improvement with new techniques and activities & $x$ & & & $x$ & $x$ & $x$ & $x$ & $\mathrm{x}$ & & & & & $x$ \\
\hline S2- Encourage attendance using new techniques & & & & & & & & & $x$ & $\mathrm{x}$ & & & \\
\hline S3- Increase involvement with new techniques & & & & & & $x$ & & & & & $\mathrm{x}$ & $x$ & $x$ \\
\hline S4- Improve participation using new activities & & & & $x$ & & & & & & $\mathrm{x}$ & & & \\
\hline S5- Improve techniques through gradual modification & & $x$ & $x$ & & & & & & $x$ & & & & \\
\hline S6- Incorporate new activities & & & & $x$ & & & & & & & & & $x$ \\
\hline
\end{tabular}

Key: I1) Questionnaire SEEQ, 12) Course Satisfaction, I3) University questionnaire, 14) Academic evaluation, 15) Peer-to-peer evaluation, 16) Coursework Comparative Evaluation, 17) Pre-test, post-test, 18) Learning report; 19) Dedication record, I10) Hand-in record, I11) Distribution of work, I12) Filming, I13) Teacher evaluation.

\section{Discussion and results}

The information obtained from the thirteen indicators is summarised in Table 5. The teaching team analysed this data with the help of experts from the Institute ICE of the University. The six strategies from the PTI are evaluated below using this analysis of the results of the indicators.

S1- Improved learning using active techniques and activities: $14,16,17$ and 113 confirm that the PTI has managed to improve learning outcomes. 14 (Figure 1) shows that the academic grades have improved, and also demonstrates how these grades have gradually unified since the early phases. This can be clearly seen from the typical deviation as this indicator compiles data from all the phases. 16 confirms that the student learning process during the practical sessions of the course has also improved with the implementation of the PTI, and that there are more students who have obtained the knowledge and skills required with excellence and distinction. However it is important to note that this improvement has been erratic and that the worst results were found in the first courses when the PTI was applied, as the University assessors had warned in common with the literature (Biggs, 2011). 17 shows that during the phases when it was measured, the students have learnt in all the PBL which had been complemented with active teaching methods. For example, 17 confirms that the activity of model making has been extremely efficient for learning about the specific structure of a building. Finally, I13 corresponds with the results of the earlier indicators and has complemented them.

S2- Techniques for encouraging full attendance: I10 (Figure 2) has demonstrated that the PTI has increased attendance, as is also confirmed by other indicators which were not specifically intended to evaluate this task (such as I4 and I13). On the other hand 19 gives no information about the use and functioning of this strategy.

S3- Techniques for increasing involvement: 111 confirms that this strategy has been useful and that the debate technique has increased the involvement of the students. Other indicators such as 16 and $I 13$ also confirm this. I11 on the other hand has not helped in evaluating this improvement strategy. 


\begin{tabular}{|c|c|}
\hline Indicator & Main Results \\
\hline 11 & $\begin{array}{l}\text { Interaction with the group is the most highly rated aspect during the initial phases of the PTI. } \\
\text { The overall vision of the course and the learning process are the most poorly evaluated aspects during the initial phases of the PTI. } \\
\text { Participation increases, however students become more dissatisfied with the courses during the initial phases of the PTI. }\end{array}$ \\
\hline 12 & $\begin{array}{l}\text { Group work and the use of coursework exercises are evaluated best during the final stages of the PTI. } \\
\text { Completion of I18 and I19 by students and staff are evaluated most poorly during the final stages of the PTI. }\end{array}$ \\
\hline 13 & Staff evaluations show a tendency towards improvement. \\
\hline 14 & $\begin{array}{l}\text { Academic grades have improved and become more homogeneous. } \\
\text { Participation has increased. }\end{array}$ \\
\hline 15 & Peer evaluation has not helped to evaluate the learning process. \\
\hline 16 & Student coursework shows that the learning outcomes have improved. \\
\hline 17 & Students have learnt new skills and knowledge. \\
\hline 18 & The learning questionnaires have not helped to evaluate the learning process. \\
\hline 19 & $\begin{array}{l}\text { The record of dedication has not helped to record either attendance or student satisfaction. } \\
\text { Staff dedication during classes has helped to improve the insertion of the PTI from phase to phase. }\end{array}$ \\
\hline 110 & The percentage of full hand-ins has increased. \\
\hline 111 & Sharing out work has had little impact on increasing student involvement. \\
\hline 112 & Students have become highly involved in the debates. \\
\hline 113 & $\begin{array}{l}\text { The student learning process has improved with this PTI. } \\
\text { Staff dedication outside the classroom has increased, especially in the initial phases of the PTI. } \\
\text { The greater part of the PTI strategies have been successful with the exception of some activities and indicators which require improvement } \\
\text { or substitution. }\end{array}$ \\
\hline
\end{tabular}

Key: I1) Questionnaire SEEQ, 12) Course Satisfaction, 13) University questionnaire, 14) Academic evaluation, I5) Peer-to-peer evaluation, I6) Coursework Comparative Evaluation, 17) Pre-test-post-test, 18) Learning report; 19) Dedication record, I10) Hand-in record, I11) Distribution of work, I12) Filming, I13) Teacher evaluation.

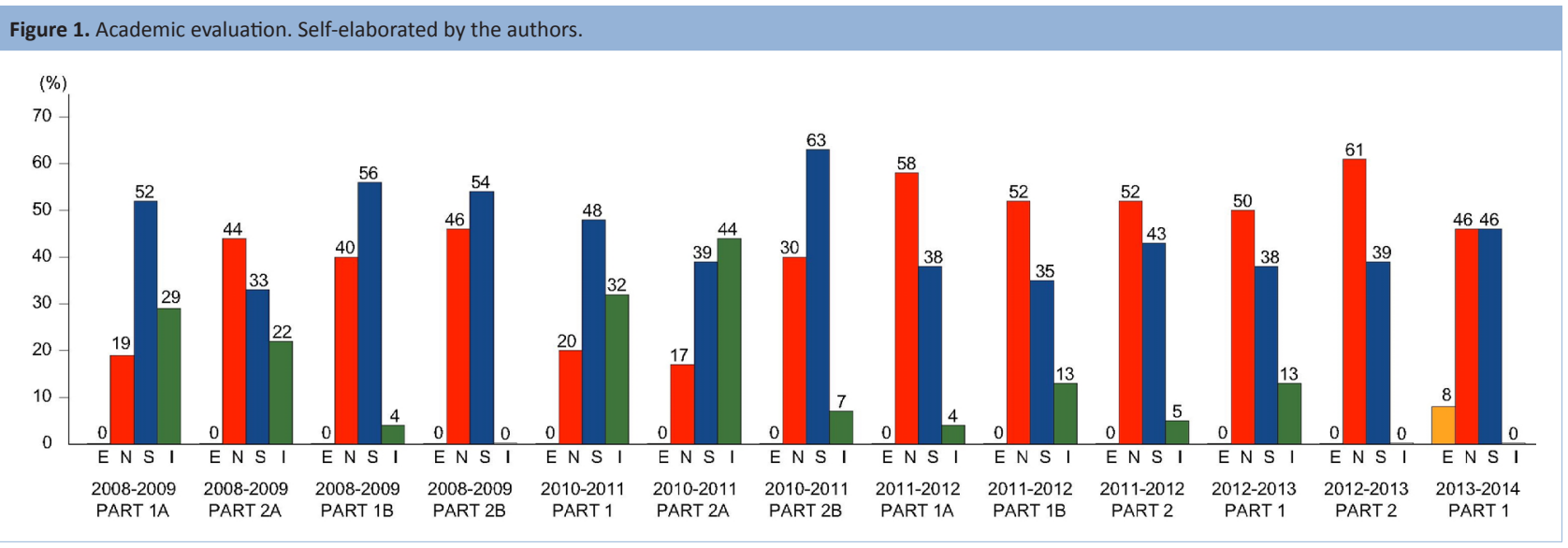

Key (Grades out of 10):

$\mathrm{E}=$ Excellent, between 9 and 10, demonstrating that students have learnt the maximum expected of them

$\mathrm{N}=$ Good, between 7 and 8 , demonstrating that students have learnt more than the minimum required

$\mathrm{S}=$ Pass, between 5 and 7 , demonstrating that students have learnt the minimum required

I= Fail, less than 5 , demonstrating that students have learnt less than the minimum required.

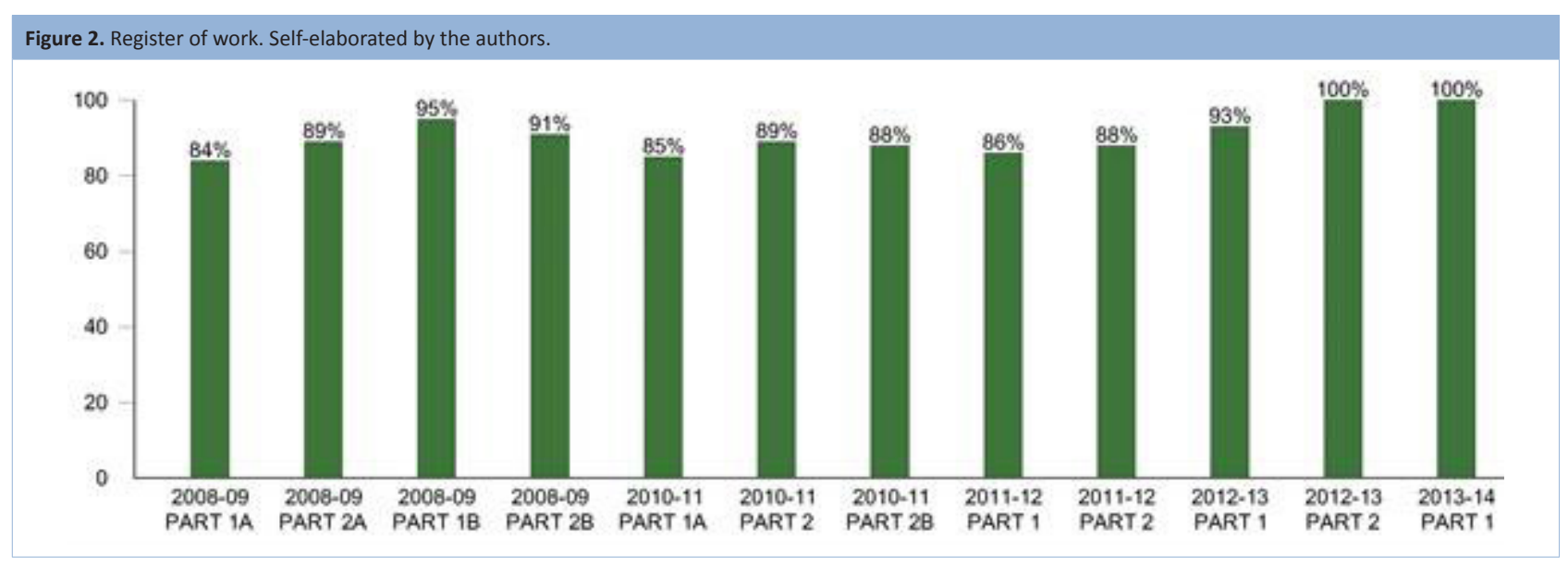




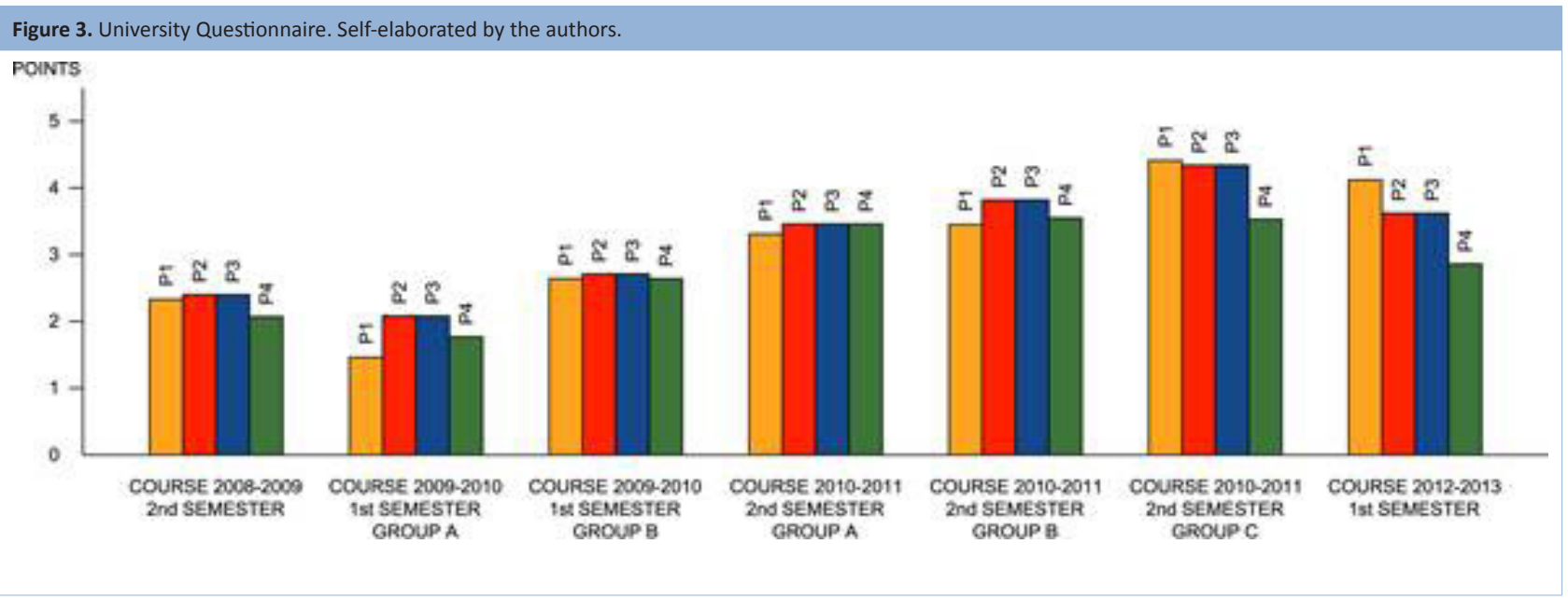

Key

P1) I believe that this professor has helped me to understand this material.

P2) I think that the teacher is motivated in the material being taught.

P3) I consider that the teacher appears receptive in resolving the doubts of the students.

P4) I think that the professor who has taught this course is a good teacher

S4- Activities for improving participation: 14 and 110 demonstrate that the PTI has increased participation because the percentage of hand-ins has increased while fewer students have abandoned the course.

S5- Activities for meeting students' expectations: 12 and 13 (Figure 3) show that student satisfaction with teachers and the course has increased, although 19 has not helped to evaluate this. 12 demonstrates that from the third phase onwards, new active methods were already achieving the desired results but were still in the final phase of perfection. 12 compiled the results from I1 and later phases, and showed that students clearly continued to evaluate the group work as the most positive, and that practical exercises help them to understand the theory. The negative aspects were similar but more dispersed: a) the indicators completed by the students (dedication time and learning reports), b) organizational, such as the lack of coordination between theory and practice. 13 shows that teacher evaluations have also improved with the introduction of the new project, even though in phase 4 student satisfaction has declined, which might be explained by problems with the functioning of certain activities inherited from other phases owing to the increase in the student ratio per group.

S6- New activities to address the competencies: 14 and 113 show that work has been done to satisfy the six generic competencies (ICE, 2008), and that these have been achieved in part. However the digital portfolio activity still has not fully worked as shown in various different versions. In contrast to other successful cases (Franquesa et al., 2013), in this particular one, the portfolio was not the principal activity but rather part of several others. It is considered that for it to work as a secondary activity, it would need to form part of a larger project in which all the courses across the whole degree would participate (Genís et al., 2012).

The indicators have also provided other information of use to the PTI which are described below:

a) The results of $I 1$, when taken together, are slightly negative about the new teaching project presented here but with the positive side that participation has increased by around $6 \%$. The explanation noted by the researchers is that the previous phases with better results were conducted using an older consolidating and contrasting methodology, while the first three phases of the PTI were still experimental and therefore obtained worse results. This hypothesis is corroborated by the least valued aspects of the new project in 12 which are: the overall vision, learning outcomes, coursework and group interaction. The work-load is criticised as much in the new project as in previous phases. To summarise, it is considered that this indicator demonstrates that during the third phase, the new project was already achieving some of its initial objectives at the point when most of the active methods had already been implemented, even though various general aspects of the functioning of the course still required refining.

b) 15: the numerous successes compiled in the technical bibliography (Valero-García et al., 2005), have not worked for the purposes of evaluation in the PTI, because very few students have brought up constructive criticisms and the evaluation of students and professors has only coincided in a very few cases. It has however served to provide self-motivation for the students. However, as this indicator was applied only in one instance, it does not serve as a general rule.

c) 18 has still not been applied successfully. It was originally considered to be extremely useful from the students' perspective; however, as the students showed dissatisfaction with this indicator from the beginning, it was decided to leave out this indicator after two phases and apply its analysis in a future phase. Students saw it as extra work which did not serve to improve their final grade and so its real importance would need to be demonstrated to the students (Felder \& Brent, 1994).

d) The same situation has occurred in 19 as in 17. Recording the teacher's dedication to the class has been very useful for adjusting each one of the active methods to the course timetable during the subsequent phases of the project.

e) The same has occurred in 111 as in 18 and 17 . Unequal and non-consensual distribution of work has only been detected in a few cases, nevertheless this has been useful for grading purposes.

f) I12 has helped to improve the debate. As a result, professors have a more active role in it and encourage more general participation and debate among students, add occasional comments in order to generate debate between the different groups and lead the exercise towards final conclusions.

g) I13 shows that the teachers' dedication to the course outside of the classroom was greater during the initial phases of the activities with active methods, until these became consolidated in the more advanced phases, professors were 
trained and puzzles material used during the previous course could be updated and reused. I13 also shows that problems have arisen with certain consolidated activities such as the debate, when class sizes increased by almost $100 \%$ in phase 6 . Bearing in mind the number of students, an attempt was made to split the group but this was not successful.

\section{Conclusions}

This PTI has managed to start solving the endemic problems of the PBL for the Construction 1 course at ETSAB. A progressive improvement in learning, participation, student involvement and satisfaction, as well as bringing in competencies extending across the whole course demonstrate this problem-solving tendency. Therefore the improvement strategies based on the incorporation of new active and co-operative techniques and activities have worked successfully, as is confirmed by the results and their evaluation in the previous section. Nevertheless the way is still open for further improvement hence it is advisable to continue applying this PTI and its continued improvement through collecting and analysing indicators in real time.

The principal innovation of this research is that three new activities and seven active and co-operative learning techniques have been applied progressively to improve a PBL in a specific case of learning architectural construction (Table 3). The majority of these techniques and activities have improved the studied PBL and make them relevant for studying specific aspects of teaching architectural construction. Another important innovation is recording the progress of the PTI using the 13 indicators, which has been a positive experience because most of these indicators have helped successfully to evaluate and improve the project. This is exclusively the case of the indicators that required little participation and dedication on the part of students and teachers. Both innovations agree with the technical literature in advising the slow and gradual introduction of new learning activities in order to be able to: improve or remove them in time if needed and, in the initial stages of each activity, manage the required greater dedication on the part of the professors who still have to gain experience.

The authors of this research have judged this PTI and the techniques and activities introduced to be positive and encourage the university education community to apply similar projects to improve learning. Despite the specific nature of the research, it confirms that with first hand knowledge and care the strategies, techniques and activities of this PTI may be applied to other areas of architecture and other disciplines, although it would need to be adapted to the particularities of each case.

\section{Acknowledgements}

This research is part of the research project "Elearning 3.0 in the teaching of architecture. Case studies of edicational research for the foreseeble future" with Reference EDU2012-37247/EDUC from the Spanish Ministry of Economy and Competiveness. The authors would like to thank the Gilda research group, the ICE, Ernest Redondo, Jordi Franquesa and Miguel Valero.
Aebli, H. (2002). 12 formas básicas de enseñar. Una didáctica basada en la psicología. (12 basic ways of teaching. A psychology based didactic.) Madrid: Narcea.

Allen, M. J. (2004). Assessing academic programs in higher education. Bolton, MA: Anker.

Aronson, E. (2000-2014). Jigsaw Classroom. Resource document. Elliot Aronson. [Retrieved from http://www.jigsaw.org/ visited 7.04.14]

Barrows, H. S. \& Tamblyn, R. M. (1980). Problem-based learning: An approach to medical education. New York: Springer.

Barrows, H. S. (1992). The tutorial process. Springfield, IL: Southern Illinois University School of Medicine.

Biggs, J. \& Tang, C. (2011). Teaching for Quality Learning at University. U.S.A.: McGraw Hill.

Bonwell C.C. \& Eison J.A. (1991). Active Learning: Creating Excitement in the Classroom. ASHE-ERIC Higher Education Report N. 1. Washington, DC: The George Washington University, School of Education and Human Development.

Brown, C. (2008). Targeted Assessment Rubric: an empirically grounded rubric for interdisciplinary writing. The Journal of Higher Education, 80 (3), 334-353.

Cambpbell, M., Liebowitz, M., Mednick, A. \& Rugen, L. (1998). Guide for Planning a Learning Expedition. Expeditionary learning. Outward Bound Inc. Dubuque, IA: Kendall/Hunt.

Dimitrov, D. M. \& Rumrill, P. D. (2003). Pretest-posttest designs and measurement of change. Work 20 Speaking of Research 159-165. [Retrieved from http://www.phys.Isu.edu/faculty/ browne/MNS_Seminar/JournalArticles/Pretest-posttest_design. pdf visited 03.05.14]

Faickney, A. (1963). Applied Imagination: Principles and Procedures of Creative Problem Solving. New York: Charles Scribner's Sons.

Felder, R. M. \& Brent, R. (1994). Co-operative learning in technical papers: Procedures, pitfalls, and payoffs. in ERIC Document Reproducion Service Report ED 377038. [Retrieved from http://ncsu.edu/felder-public/Papers/Coopreport.html visited 10.04.14]

Fitzgerald, D. (2013). Employing think-pair-share in associate degree nursing curriculum. Teaching and Learning in Nursing, 8 (3), 88-90.

Franquesa, J., Moreno, J. \& Elinbaum, P. (2013) The e-Portfolio for understanding the city. Recent Advances in Educational Technologies; 40-45. [Retrieved from http://www.wseas. us/e-library/conferences/2013/CambridgeUSA/EET/EET-06.pdf visited 03.05.14]

Genís, M., Devesa, R. \& Franquesa, J. (2012). La gestació i gestió d'un grup d'interès: L'experiència de Gilda. Jornada d'Innovació Docent - RIMA, 259-258. [Retrieved from http:// upcommons.upc.edu/revistes/bitstream/2099/12492/1/14-GILDA-1-MGenis-249-258.pdf visited 03.05.14]

Gonzalez, M., Kulakowski, M., Breitenbach, L. \& Kirch F. (2014). A case study about embodied energy in concrete and structural masonry buildings. Journal of Construction, 13(2), 9 - 14.

Hussain, R. M. R., Mamat, W. H. W., Salleh, N., Saat, R. M. \& Harland, T. (2007). Problem-based learning in Asian universities. Studies in Higher Education, 32(6), 761 - 772.

Institut de Ciències de l'Educació (Institute of Education Science, ICE - 2008. Summary of the generic competencies and their development in UPC undergraduate curricula. [Retrieved from http://www.upc.edu/ice/innovacio-docent/publicacions_ice/ arxius/resum_competencies_eng.pdf/view visited 09.04.14] 
King, L. (2002). Preparing EFL Learners for Oral Presentations. Journal of Humanistic studies, 4, 401-418. [Retrieved from http://www1.lib.ndhu.edu.tw/libhtml/series/200204/4-401-418. pdf visited 10.04.14]

Koh, G. C., Khoo, H. E., Wong, M. L. \& Koh, D. (2008). The effects of problem-based learning during medical school on physician competency: A systematic review. Canadian Medical Association Journal, 178(1), 34-41.

Kumar, M. \& Natarajan, U. (2007). A problem-based learning model: Showcasing an educational paradigma shift. Curriculum Journal, 18(1), 89-102.

Lyman, F. T. (1981). The responsive classroom discussion: the inclusion of all students. In A. S. Anderson (Ed.), Mainstreaming Digest (109-113). College Park, MD: University of Maryland Press.

Parcher, J. (1998). The Value of Debate. Adapted from the Report of the Philodemic Debate Society, Georgetown University. [Retrieved from http://www.principlestudies.org/docs/The_Value_ of_Debate_Secular.pdf visited 09.04.14]

Pérez-Martínez, J.E., García, J., Muñoz, I. \& Sierra-Alonso, A. (2010). Active Learning and Generic Competences in an Operating Systems Course. International Journal of Engineering Education, 26(6), 1484-1492. [Retrieved from [Retrieved from http://c3po.eui.upm.es/dmae/Publicaciones/17_ljee2387. pdf visited 03.05.14

Pinto, R. (2011). Doing more with less: Architectural Education in challenging times. 14th EAAE-ENHSA Meeting of Heads of Schools of Architecture. Center for Mediterranean Architecture. Chania, Crete. [Retrieved from http:// upcommons.upc.edu/e-prints/bitstream/2117/17995/1/Doing\%20 more\%20with\%20less\%20finances_Rita\%20 Pnto\%20de\%20 Freitas.pdf visited 11.04.14]

Pons, O., Gonzàlez, J. M., Ramos, A., López, R. \& Gumà, R. (2012). Recomanacions pels puzles en l'aprenentatge de la construcció a l'arquitectura (Recommendations for puzzles used to learn the construction of architecture). Jornada d'Innovació Docent - RIMA, 278-288. [Retrieved from http:// upcommons.upc.edu/revistes/bitstream/2099/12665/1/14-GILDA4-OPons-278-288.pdf visited 03.05.14]

Prince, M. J. (2004). Does active learning work? A review of the research. Journal of Engineering Education, 93(3), 223-31.
Richardson, J. T. E. (2005). Instruments for obtaining student feedback: a review of the literature, Assessment \& Evaluation in Higher Education, 30:4, 387-415. [Retrieved from http://www.jcu.edu.au/learnandteach/public/groups/ everyone/documents/how_to/jcu_121465.pdf visited 03.05.14]

Ruiz, P. (2012). Portafolio. Resource document. http://www.wix.com/ patriciaruiz92/construccin Accessed 10 April 2014.

Sánchez, J., Ruiz, J. \& Sánchez, E. (2011). Análisis comparativo de evaluación entre pares con la del profesorado. Un caso práctico. Revista Docencia e Investigación. 21. [Retrieved from http://www.uclm.es/varios/revistas/docenciaeinvestigacion/ pdf/numero11/01.pdf visited 03.05.14]

Takahashi, S. \& Saito E. (2013) Unraveling the process and meaning of problem-based learning experiences. Higher Education 66, 693-706.

Tempelaar, D. T., Wosnitza, M., Volet, S., Rienties, B., Giesbers, B. \& Gijselaers, W. H. (2013) The role of self- and social directed goals in a problembased, collaborative learning context. Higher Education, 66, 253-267.

Thomas, J. W. (2000). A Review of Research on Project Based Learning. San Rafael, California: The Autodesk Foundation. [Retrieved from http://www.bobpearlman.org/BestPractices/PBL Research.pdf visited 09.04.14]

Traver, J. A. \& García, R. (2006). La técnica puzzle de Aronson como herramienta para desarrollar la competencia "compromiso ético" y la solidaridad en la enseñanza universitària. (Aronson's puzle technic as a tool to develop the "ethic compromise and the solidarity in university education). Revista Iberoamericana de Educación. 40(4), 1-9.

Tuncay, N. \& Ekizoglu, N. (2010). Bridging achievement gaps by "free" project based learning. WCES-2010. Procedia Social and Behavioral Sciences 2. 5664-5669.

Valero-García, M. \& Díaz de Cerio. L.M. (2005). Autoevaluación y co-evaluación: estrategias para facilitar la evaluación continuada. Sindi, [Retrieved from http://epsc.upc.edu/ projectes/usuaris/miguel.valero/materiales/docencia/articulos/ SINDI2005.pdf visited 03.05.14]

Wesel, M. V. \& Prop, A. (2008). The influence of Portfolio media on student perceptions and learning outcomes. Student Mobility and ICT: Can E-LEARNING overcome barriers of Life-Long learning Conference, Maastricht. 